\title{
Kandungan Antioksidan Teh Hijau Daun Mangrove dan Uji Efektifitasnya Sebagai Antikolesterol Pada Mencit
}

\author{
Analuddin', Andi Septiana1), Wa Ode Harlis ${ }^{2)}$ \\ ${ }^{1}$ Program Studi Bioteknologi, FMIPA, Universitas Halu Oleo, Kendari \\ ${ }^{2}$ Program Studi Biologi, FMIPA, Universitas Halu Oleo, Kendari \\ Jl. H.E.A.Mokodompit Kampus Hijau Bumi Tridharma, Anduonohu, Kendari 93232 \\ Email korespondensi: zanzarafli@gmail.com
}

(Diterima: 18-8-2018; disetujui 22-9-2018)

\begin{abstract}
ABSTRAK
Penelitian ini bertujuan untuk menentukan senyawa antioksidan teh hijau dan menjelaskan efektifitas teh hijau daun mangrove sebagai anticholesterol pada mencit. Senyawa kimia bahan antioksidaan teh hijau pada daun mangrove Bruguiera gymnorrhiza, B. parviflora, Rhizophora stylosa, R. mucronata, Lumnitzera racemosa, Ceriops tagal dan $C$. decandra dianalisis dengan GCMS, sedangkan khasiat teh hijau daun mangroves sebagai antikolesterol di ujikan pada mencit. Hasil penelitian menunjukan bahwa senyawa bahan teh hijau bervariasi diantara daun mangrove yaitu polifenol sederhana ditemukan pada daun semua jenis mangrove yang menjadi sampel penelitian dengan konsentrasi yang bervariasi. Senyawa katekin hanya ditemukan pada daun mangrove Ceriops decandra, L. racemosa, $R$. mucronata dan $R$. apiculata. Di sisi lain, flavonoid terdeteksi hanya pada daun $C$. tagal, B. gymnorrhiza dan $R$. stylosa, sedangkan senyawa T-flavin hanya ditemukan pada daun $B$. parviflora. Teh hijau daun mangrove mampu menurunkan kadar kolesterol mencit dengan kisaran 33,33 sampai 53,67\% mengindikasikan besarnya potensi daun mangrove sebagai bahan teh hijau antikolesterol.
\end{abstract}

Kata kunci: bahan teh hijau, polifenol sederhana, katekin, flavonoid, antikolesterol, daun mangrove

\begin{abstract}
This study aimed to determine the antioxidant properties of green tea material in mangrove leaves and elucidate their capacity on reducing the cholesterol of mice. The chemical properties in leaves of Bruguiera gymnorrhiza, B. parviflora, Rhizophora stylosa, R. mucronata, Lumnitzera racemosa, Ceriops tagal and $C$. decandra were analyzed by GCMS, while their capability as anticholesterol of mice were examined. The results showed that simple polyphenols were found in all sampled mangrove leaves with different concentration, while the chatechine was found only in leaves of four mangroves including Ceriops decandra, L. racemosa, $R$. mucronata and $R$. apiculata. On the other hand, flavonoids was detected only in leaves of C. tagal, B. gymnorrhiza and R. stylosa. Meanwhile, T-flavine was detected only in leaves of B. parviflora. However, green tea material for all of sampled mangroves showed high capacity to reduce cholesterol of mice that ranging from $33.33 \%$ to $53.67 \%$, which indicated high potentitiality of mangroves leaves as green tea material of anticholesterol.
\end{abstract}

Keywords: Green tea material, simple polyphenol, cathechin, flavonoid, anticholesterol, Mangroves leaves 


\section{PENDAHULUAN}

Teh hijau merupakan salah bahan kajian sangat menarik karena manfaatnya yang sangat penting untuk penyembuhan berbagai macam penyakit (Masek et al., 2017). Teh hijau umumnya dibuat dari tumbuhan Camelia sinensis mengandung antioksidan seperti katekin, vitamin C dan lain-lain (Graham, 1992). Teh hijau merupakan produk non fermentasi dengan kandungan katekin yang tinggi (Wang et al., 2000; Kodama et al., 2010; Namita et al. 2012) dan memiliki aktifitas antioksidan baik pada kondisi in vitro maupun in vivo (Cabrera et al.. 2006; Namita et al., 2012).

Senyawa kimiawi the hijau umumnya adalah katekin, galokatekin, flanol, polifenol sederhana maupun tannin (Harbowy \& Douglas, 1997). Senyawa aktif dalam teh yang berperan sebagai antioksidan adalah polifenol. Senyawa polifenol yang berperan sebagai antioksidan banyak ditemukan pada tumbuhtumbuhan. Polifenol dalam tumbuhan teresterifikasi dengan glukosa, dan glikosida atau berupa aglikon bebas (Alexis Biochemical, 2008).

Penyakit diabetes melitus dan kolesterol merupakan masalah serius di Indonesia karena menyerang pada hampir semua lapisan umur (Kemenkes RI, 2014), sedangkan upaya pengobatan pumumnya menggunakan obat antibiotik yang dapat menimbulkan masalah karena sebagian besar bahan antibiotik yang digunakan sifatnya tidak aman bagi kesehatan sehingga diperlukan penemuan bahan obat bersumber dari alam yang kurang efek sampingnya. Beberapa jenis tumbuhan diketahui mengandung bahan alam yang dapat menurunkan kadar glukosa darah sekaligus kolesterol dalam darah diantaranya sambiloto dan propolis (Rammohan, 2008).

Tumbuhan mangrove merupakan sumber daya hayati yang sangat penting di Sulawesi Tenggara karena mendukung kehidupan hewan-hewan endemik seperti Anoa (Buballus $s p$ ) dan Elang Sulawesi serta mengandung antioksidan dan nutrisi yang potensial untuk dimanfaatkan bagi kesejahteraan manusia (Andi Septiana et al., 2016). Mangrove di Sulawesi Tenggara seperti di Taman Nasional Rawa Aopa Watumohai sangat beranekaragam dan didominasi oleh
Rhizophora apiculata, $R$. mucronata, Ceriops tagal dan Xylocarpus granatum (Analuddin et al., 2013) dan mengalami degradasi yang serius sehingga perlu penelitian dan pengelolaan untuk menjamin kelestarian ekosistem mangrove dan kesejahteraan masyarakat.

Tumbuhan mangroves berkembang di lingkungan ekstrim karena kemampuannya memproduksi metabolit sekunder dan bertindak sebagai antioksidan untuk beradaptasi terhadap berbagai faktor lingkungan ekstrim dipantai. Antioksidan dapat melindungi tumbuhan terhadap stress lingkungan, baik biotik maupun abiotik stress serta mencegah terbentuknya senyawa radikas bebas reactive oxigen spesies ROS yang berbahaya bagi tumbuhan. Herwati (2011) melaporkan bahwa tumbuhan mangrove Sonneratia alba berpotensi sebagai sumber antioksidan alami. Hal ini memberikan peluang untuk diversifikasi pemanfaatan mangroves secara berkelanjutan melalui penemuan sumber bahan obat alamidan berbagaiperuntukan lain bagi dimasyarakat. Tujuan penelitian adalah (1) untuk menentukan kandungan kimiawai teh hijau sebagai bahan antioksidan pada daun mangroves dan (2) menguji efektifitas teh hijau daun mangrove sebagai antikolesterol pada mencit.

\section{METODE PENELITIAN}

\section{Analisis senyawa kimia teh hijau daun mangrov}

Skreening ekstrak daun berbagai jenis mangroves untuk mengetahui kandungan bahan kimiawi pada daun-daun muda mangroves sebagai bahan teh hijau dilakukan dengan menggunakan Gas Chromatography Mass Spectrophotometer GCMS. Daun-daun muda dari jenis Lumnitzera racemosa, Bruguiera gymnorrhiza, B. parviflora, Rhizophora apiculata, $R$. mucronata, $R$. stylosa, Ceriops tagal dan Ceriops decandra diambil langsung di Taman Nasional Rawa Aopa Watumohai dan ditempatkan pada Box berisi Es Kering. Selanjutnya di eksraksi di laboratorium Forensik FMIPA UHO. Skreening ekstrak daun berbagai jenis mangrove dilakukan dengan menggerus daundaun kemudian ditambahkan aquades dan beberapa bahan kimiawi dan disentrifugasi. 
Hasil sentrifugasi diambil cairan kemudian dilakukan pembacaan absorbansi dengan GCMS dan dilanjutkan pengamatan sampel dengan metode chromatography.

\section{Uji efektifitas teh hijau daun mangrove sebagai antikolesterol}

Sebanyak 50 ekor hewan mencit jantan diaklimatisasi selama 10 hari di Laboratorium Zoologi Jurusan Biologi FMIPA, UHO. Mencit peliharaan diberikan makanan/pakan standar campuran antara beras dan jagung yang tidak halus. Hewan uji dikontrol dengan pemeriksaan darah secara berkala dan untuk memastikan kesehatan hewan uji sebelum dilakukan perlakuan. Mencit dibagi menjadi 8 kelompok masingmasing 3 ekor mencit. Semua hewan uji dipuasakan selama 8 jam kemudian diukur kadar kolesterol sebelum perlakuan dengan menggunak KIT Kolesterol. Selanjutnya hewan uji diperlakukan sebagai berikut:

- Kelompok I diberikan pakan standar (kontrol negatif)

- Kelompok II diberikan pakan kuning telur dan daging sapi (kontrol positif)

- Kelompok III diberikan pakan dengan kadar kadar kolesterol tinggi dan diperlukan dengan teh hijau dari ekstrak daun Ceriops decandra

- Kelompok IV diberikan pakan dengan kadar kadar kolesterol tinggi dan diperlukan dengan teh hijau dari ekstrak daun Ceriops tagal

- Kelompok V diberikan pakan dengan kadar kadar kolesterol tinggi dan diperlukan dengan teh hijau dari ekstrak daun Rhizophora mucronata

- Kelompok VI diberikan pakan dengan kadar kadar kolesterol tinggi dan diperlukan dengan teh hijau dari ekstrak daun Bruguierra gymnorrhiza

- Kelompok VII diberikan pakan dengan kadar kadar kolesterol tinggi dan diperlukan dengan teh hijau dari ekstrak daun Bruguierra parviflora.

- Kelompok VIII diberikan pakan dengan kadar kadar kolesterol tinggi dan diperlukan dengan teh hijau dari ekstrak daun Lumnitzera racemosa.

Pemberian ekstrak teh hijau daun mangrove kepada hewan uji dilakukan selama 14 hari. Setelah itu hewan uji dipuasakan selama 8 jam, kemudian diukur kadar kolesterol darahnya menggunakan KIT Kolesterol.

\section{HASIL DAN PEMBAHASAN}

\section{Kandungan kimiawi teh hijau daun mangrove}

Hasil analisis kandungan kimiawi bahan teh hijau pada daun mangrove Ceriops tagal, Bruguierra gymnorrhiza, B, parviflora, Rhizophora apiculata, $R$. mucronata, $R$. stylosa, Lumnitzera racemosa, Ceriops tagal dan Ceriops decandra ditampilkan pada Tabel 1 menunjukan bahwa daun $B$. parviflora mengandung lebih banyak polifenol sederhana $(10,27 \%)$ dibandingkan jenis-jenis mangrove lainnya. Nampaknya daun-daun mangroves Rhizophoraceae kecuali $R$. apiculata dan $C$. tagal mengandung polifenol sederhana lebih dari $5 \%$. Demikian juga daun L. racemosa mengandung polifenol hampir 7\%. Handayani dkk (2014) melaporkan bahwa kadar polifenol total pada Camellia sinensis berkisar 7.1\%. Hasil penelitian ini menunjukan bahwa kadar polifenol daun mangroves cukup tinggi yaitu $10,27 \%$ untuk $B$. parviflora, $8,21 \%$ untuk $B$. gymnorrhiza, 7,07\% untuk $R$. stylosa, 6,81\% untuk daun L. racemosa dan Analuddin et al. (2016) melaporkan bahwa kadar polifenol sederhana pada daun $R$. mucronata sebsar 6,41\%. Bindhu et al. (2015) menyatakan bahwa teh hijau Camellia sinensis mengandung senyawa polifenol yang cukup tinggi.

Kadar katekin pada daun mangrove bervariasi yaitu $1,71 \%$ pada daun L. racemosa, dan Analuddin et al. (2016) melaporkan bahwa kadar katekin sebesar $1.83 \%$ untuk daun Ceriops decandra, 1,14\% pada daun $R$. mucronata dan $0,83 \%$ pada daun $R$. apiculata, namun tidak terdeteksi pada daun mangrove $C$. tagal, B. parviflora dan B. gymnorrhiza. Sebaliknya flavonoid hanya terdeteksi pada daun $B$. gymnorrhiza sebesar $1,64 \%$ dan daun $R$. stylosa sebesar $0,73 \%$ dan di laporkan oleh Analuddin et al. (2016) bahwa kadat flavonoid pada daun C. tagal sebesar $1,13 \%$, Handayani dkk (2014) melaporkan bahwa kadar katekin dan total flavonoid pada Camellia sinensis masing-masing hanya sebesar $0,83 \%$ dan $1,04 \%$. Cho et al. (2007) menyatakan bahwa katekin adalah senyawa yang sangat berperan secara biologi dalam aktifitas tubuh manusia. Beberap penelitian menunjukan bahwa pengaruh yang sangat kuat dari katekin karena kandungan epikatekin dan epigalokatekin yang paling dominan pada teh hijau (Li et al., 2009, Tosun et al., 2009; Zahim et al., 2009). Hal ini mengindikasikan tingginya potensi daun berbagai jenis mangroves sebagai bahan teh hijau. 
Tabel 1. Kandungan antioksi dan bahan tea hijau 8 jenis mangrove

\begin{tabular}{|c|c|c|c|c|c|}
\hline No & Mangrove & Katekin (\%) & $\begin{array}{c}\text { Polifenol } \\
\text { sederhana }(\%)\end{array}$ & $\begin{array}{c}\text { Senyawa } \\
\text { flavonoid }(\%)\end{array}$ & $\begin{array}{c}\text { T-flavin } \\
(\%)\end{array}$ \\
\hline 1 & Ceriops tagal & & 2,97 & 1,13 & \\
\hline 2 & Rhizophora. apiculata & 0,83 & 4,81 & & \\
\hline 3 & Bruguiera parviflora & & 10,27 & & 0,60 \\
\hline 4 & B. gymnorrhiza & & 8,21 & 1,64 & \\
\hline 5 & R. stylosa & & 7,07 & 0,73 & \\
\hline 6 & R. mucronata & 1,14 & 6,41 & & \\
\hline 7 & Lumnitzeraracemosa & 1,71 & 6,81 & & \\
\hline 8 & Ceriopsdecandra & 1,83 & 5,58 & & \\
\hline
\end{tabular}

Beberapa jenis mangrove dapat digunakan sebagai obat tradisional yaitu Rhyzopora mucronata sering digunakan untuk menghentikan pendarahan, Ceriops tagal dapat digunakan sebagai antiseptik luka (Henny et al., 2017). Hal ini menunjukan bahwa ekstrak mangrove mungkin dapat menyembuhkan berbagai penyakit, karena mengandung senyawa kimia yang bermanfaat seperti flavonoid, saponin, tannin dan tokoferol (Purnobasuki, 2004). Senyawa metabolit sekunder juga berfungsi sebagai antioksidanyang dapat menghambat oksidasi radikal bebas (Rafsanjani dan Putri, 2015). Beberapa hasil penelitian menunjukkan bahwa ada beberapa jenis tanaman memiliki kandungan senyawa antioksidan seperti fenolik, flavonoid, alkaloid dan terpenoid lebih efektif dan lebih aman dari pada antioksidan sintetis (Inggrid \& Santoso, 2014).

Katekin dapat membuang kolesterol melalui feses (Rosydi, 2014). P emberian asupan flavonoid dapat menurunkan resiko munculnya kolesterol yang berlebihan (Subroto \& Saputro, 2008).

\section{Efektifitas teh hijau daun mangrove sebagai antikolesterol}

Hasil perlakuan ekstrak teh hijau beberapa jenis mangrove terhadap kolesterol mencit (Tabel 2) menunjukan bahwa persentasi penurunan kadar kolesterol mencit cukup tinggi dengan pemberian teh hijau daun mangrove yaitu penurunan sebesar 53,67\% untuk B. parviflora, $52,33 \%$ untuk $B$. gymnorrhiza, 50,33\% untuk Ceriops tagal, $49,33 \%$ untuk $C$. decandra, dan $42,33 \%$ untuk Rhizophora mucronata, serta $33,33 \%$ untuk $L$. racemosa. Dengan demikian teh hijau daun mangrove sangat efektif sebagai antikolesterol. Gomikawa et al. (2008) melaporkan bahwa senyawa katekin teh hijau dapat menurunkan resiko penyakit jantung koroner karena kadar kolesterol dalam plasma dan LDL menurun 10 $\mathrm{mg} / \mathrm{dl}$ setelah mengkonsumsi teh hijau. Beberapa penelitian sebelumnya juga melaporkan bahwa minuman teh hijau berpengaruh pada kerentanan plasma dan LDL terhadap oksidasi (Gomikawa \& Ishikawa, 2002; Hodgson et al., 2002; Koga and Medyani, 2001). Maron et al. (2003) melaporkan bahwa ekstrak teh hijau menurunkan kolesterol serum dan LDL masing-masing.sebesar $11,3 \%$ dan $16,4 \%$.

Hasil penelitian Gomikawa et al. (2008) menunjukkan bahwa konsumsi teh hijau tanah (1,5 g/3kali/hari) menurunkan kadar kolesterol dalam plasma dan LDL. Hal ini sesuai juga dengan beberapa penelitian sebelumnya pada manusia dan hewan (Loest et al., 2002; Maron et al., 2003). Teh hijau merupakan tumbuhan obat yang dapat menurunkan kolesterol dan trigliserida, serta glukosa, dan dapat mencegah karies pada gigi (Burnetto et al., 1999; Murase et al., 2000). Bursil et al. (2007) melaporkan bahwa teh hijau dapat menurunkan kolesterol dalam plasma Kelinci. 
Tabel 2. Persentasi penurunan kolesterol pada mencit dengan pemberian teh hijau 6 jenis mangrove

\begin{tabular}{llc}
\hline No & Mangrove & $\begin{array}{c}\text { Rerata } \\
\text { Penurunan Kolesterol mencit (\%) }\end{array}$ \\
\hline 1 & Teh hijau Rhizophora mucronata & $42,33 \pm 6,77$ \\
2 & Teh hijau Bruguiera gymnorrhiza & $52,33 \pm 6,23$ \\
3 & Teh hijau Ceriops decandra & $49,33 \pm 7,54$ \\
4 & Teh hijau Ceriops tagal & $50,33 \pm 19,55$ \\
5 & Teh hijau Bruguiera parviflora & $53,67 \pm 9,53$ \\
6 & Teh hijau Lumnitzera racemosa & $33,33 \pm 4,33$ \\
\hline
\end{tabular}

\section{KESIMPULAN}

Daun mangrove Bruguierra parviflora dan B. gymnorrhiza mengandung lebih banyak polifenol sedearhana $(10,27 \%$ dan $8,21 \%)$ dibandingkan jenis-jenis mangrove lainnya. Daun-daun muda hampir semua jenis mangrove mengandung senyawa katekin berkisar $0,81-1,83 \%$ yang mengindikasikan potensinya sebagai bahan teh hijau. Daun-daun muda mangrove family Rhizophoraceae mengandung polifenol sederhana $>5 \%$, dan daun Lumnizera racemosa mengandung polifenol sekitar 7\%. Uji efektifitas teh hijau daun mangrove menunjukkan bahwa ekstrak teh hijau mangrove dapat menurunkan kadar kolesterol mencit berkisar 33,33\% sampai $53,67 \%$ sehingga daun mangrove berpotensi sebagai bahan teh hijau antikolesterol.

\section{DAFTAR PUSTAKA}

Analuddin, Jamili, R. Raya, A. Septiana \& S. Rahim. 2013. The Spatial trends in the structural characteristics of mangrove at the Rawa Aopa Watumohai national Park, Southeast Sulawesi, Indonesia. Int. Res J. Plant. Sci. Vol. 4(8):214221

Analuddin, K., Jamili, A. Septiana, Wd. Harlis, I. Sahidin, U. Rianse, S. Rahim, S. Sharma \& K. Nadaoka. 2016. Blue carbon stock and green tea potential in mangroves of coral triangle eco-region, Southeast Sulawesi, Indonesia. Inter. J. Environ. 1:125-132.

Alexis Biochemical. 2008. Productline Catalog: Poliphenols (FlavonoidsStilbenoids-phenolic Acids). http:// www.alexis-biochemicals.com [23 Juli 2018].
Bindhu, A., A. Jaclyn, \& C.T. Sarna. 2015. Anticancer and antioxidant properties of flavored green tea Extracts. J. Agric. Life 2(1):15-24.

Bruneton J. 1999. Tea. Pharmacognosy Phytochemistry Medicinal Plants. 2nd ed. Intercept Ltd UK, Lavoisier Publishing Inc. New York. 1075-8.

Bursill, C.A., P.M. Abbey, \& P.D. Roach. 2007. A green tea lowers plasma cholesterol by inhibiting cholesterol synthesis and upregulating LDL receptor in the cholesterol-fed rabbit. Atherochloresis 193:86-93.

Cabrera, C., R. Artacho, \& R. Gimenez,2006. Beneficial effects of green tea review. J. Amer. Coll. Nutr. 25(2): 79-99.

Cho,K., M. Sukhthankar, S. Lee, J. Yoon, \& S.J. Baek. 2007. Green tea catechin (-) -epicatechingallate induces tumor suppressor protein ATF3 via EGR1activation. Eur. J. Cancer 43:24022412.

Gomikawa S, Ishikawa Y, W. Hayase, Y. Haratake, N. Hirano, H. Matuura, A. Mizowaki, A. Murakami, \& M. Yamamoto. 2008. Effect of ground green tea drinking for 2 weeks on the susceptibility of plasma and LDL to the oxidation ex vivo in healthy Volunteers. Kobe J. Med. Sci. 54(1): E62-E72.

Gomikawa, S. \& U.Ishikawa. 2002. Effects of catechins and ground green tea drinking on the susceptibility of plasma and LDL to the oxidation in vitro and in vivo. J. Clin. Biochem. Nutr. 32:55-68. 
Graham H.N. 1992. Green tea composition, consumption, and polyphenol chemistry. Prev. Med. 21(3):334-50.

Handayani, D., A. Mun'im \& A.S. Ranti. 2014. Optimasi ekstraksi ampas teh hijau (Camellia sinensis) menggunakan metode microwave assisted extraction untuk menghasilkan ekstrak teh hijau. Trad. Med. J. 19(1): 29-35.

Harbowy, M.E. \& A.B. Douglas. 1997. Tea chemistry. Critical Rev. Plant Sci. 16(5):415-480.

Henny, F. Diba dan S. Anwari. 2017. Tumbuhan mangrove yang berpotensi sebagai obat di kawasan PT. Kandelia Alam Kecamatan Kubu, Kabupaten Kubu Raya. Jurnal Hutan Lestari. 5(4): $1100-1110$.

Herawati, N. 2011. Potensi antioksidan ekstrak kloroform kulit batan tumbuhan mangrove (Sonneratia alba). J. Chemica 12:9-13.

Hodgson, J.M., K.D. Croft, T.A. Mori, V. Burke, L.J. Beillin, \& I.B. Puddey. 2002. Regular ingestion of tea dose not inhibit in vitro lipid peroxidation in humans. J. Nutr. 132: 55-58.

Inggrid, H.M. \& H. Santoso 2014. Ekstraksi antioksidan dan senyawa aktif dari buah kiwi (Actinidia deliciosa). Laporan Penelitian. Lembaga Penelitian dan Pengabdian kepada Masyarakat Universitas Katolik Parahyangan.

Kemenkes RI. 2014. Situasi dan Analisis Diabetes. INFODATIN, Pusat Data dan Informasi, Kementerian Kesehatan Republik Indonesia.

Kodama, D.H., A.E.S.S. Gonçalves, F.M. Lajolo \& M.I. Genovese. 2010. Flavonoids, total phenolics and antioxidant capacity: comparison between commercial green tea preparations. Cienc. Tech. Aliment. 30(4):1077-1082.

Koga, T. \& M. Meydani. 2001. Effect of plasma metabolism of $(+)$ catechin and quercetin on monocyte adhesion to human aortic endothelial cells. Am. J. Clin. Nutr. 73: 941-948.

Li, X., X. Wu \& L. Huang 2009. Correlation between antioxidant activities and phenolic contents of radix Angelicae sinensis (Danggui). Molecules 14:5349-5361.

Loest, H.B., S.K. Noh \& S.I. Koo 2002. Green tea extract inhibits the lymphatic absorption of cholesterol and $\alpha$ tochopherol in ovariectomized rat. J. Nutr. 132: 1282-1288

Masek A, E. Chrzescijanska, M. Latos, M. Zaborski \& A. Podsędek. 2017. Antioxidant and Antiradical Properties of Green Tea Extract Compounds. Int. J. Electrochem. Sci. 12:6600-6610.

Maron, D.J., G.P. Lu, N.S. Cai, Z.G. Wu, Y.H. Li, H. Chen, J.Q. Zhu, X.J. Jin, B.C. Wouters, \& J. Zhao. 2003. Cholesterol -lowering effect of a theaflavinenriched green tea extract. randomized controlled trial. Arch. Int. Med. 163: 1448-1453.

Murase T, A.Nagasawa, J. Suzuki, T. Hase \& I. Tokimitsu. 2000. Beneficial effects of tea catechins on diet-induced obesity: stimulation of lipid catabolism in the liver. Int. J. Obesity 26:14591464.

Namita, P., R. Mukesh \& K.J. Vijay. 2012. Camellia Sinensis (Green Tea): A review. Global. J. Pharmacol. 6(2):52-59.

Rammohan, S., M.Z. Asmawi \& A. Sadikun. 2008. In vitro $\alpha$-glucosida and se and aamylase enzyme inhibitory effect of Andrographis paniculata extract and andrographolide, Acta Biochimica Polonica, Vol 55(2):391-398.

Purnobasuki H. 2004. Potensi Mangrove Sebagai Tanaman Obat. Biota IX(2).

Rafsanjani, M. K. dan W. D. R. Putri. 2015. Karakterisasi Ekstrak Kulit Jeruk Bali Menggunakan Metode Ultrasonic Bath (Kajian Perbedaan Pelarut dan Lama Ekstraksi). J. Pangan dan Agroindustri (3) 4:1473-1480. 
Septiana, A., Wd. Harlis, Jamili \& K. Analuddin. 2016. Bioprospectsing: Antioxidant Source and Habitat of Endemic Animal of Bubalus sp in Rawa Aopa Watumohai National Park, Indonesia. Mal. Appl. Biol. J. 45(1): 23-34.

Subroto, A. \& H. Saputro. 2008. Gempur Penyakit dengan Sarang Semut. PT. Gramedia Pustaka Utama, Jakarta.

Tosun, M., S. Ercisli, M. Sengul, H. Ozer, T. Polat, \& E. Ozturk. 2009. Antioxidant properties and total phenolic content of eight salvia species from Turkey. Biol. Res. 42:175-181.

Yanti, E.P.R. 2017. Efek Pemberian Ekstrak Biji dan Ekstrak Daun Pepaya (Carica papaya Linn) terhadap Kadar Kolesterol Total dan Trigliserida Tikus Putih Jantan Galur Wistar (Rattus norvegicus) yang Diberi Diet Tinggi Lemak. Hang Tuah Med. J. 15(1):4152.

Wang, H., G.J. Provan \& K. Helliwell. 2000. Tea flavonoids: their functions, utilization and analysis. Trends Food Sci. Tech. 11:152-160.

Zahin, M., F. Aqil \& I. Ahmad. 2009. The in vitro antioxidant activity and total phenolic content of four Indian medicinal plants. Int. J. Pharm. Pharmatic. Sci. 1:88-95. 